Original research-Orijinal araştırma

\title{
The investigation of relationship between preeclampsia and antiphospholipid antibody syndrome
}

\author{
Preeklampsi ve antifosfolipid antikor sendromu arasındaki ilişkinin incelenmesi \\ Gökhan Açmaz*, Ahmet Tayyar, Gökalp Öner, Mehmet Tayyar \\ Obstetrics and Gynecology Clinic (G. Açmaz, MD), Kayseri Training and Research Hospital, TR- \\ 38010 Kayseri, Obstetrics and Gynecology Clinic (A. Tayyar, MD), Niğde Dr. Doğan Baran \\ Obstetrics, Gynecology and Pediatrics Diseases Hospital, TR-51000 Niğde, Department of \\ Obstetrics and Gynecology, (G. Öner, MD, Prof. M. Tayyar, MD), Erciyes University School of \\ Medicine, TR-38039 Kayseri
}

\begin{abstract}
Aim. The aim of this study was evaluate the relationship between preeclampsia and antiphospholipid antibodies. Methods. A total of 116 pregnant women between 20th and 40th weeks of gestation admitted to our department were investigated. 63 of them were allocated our preeclampsia group and 53 of them were allocated our control group. Lupus anticoagulant, anticardiolipin antibodies (IG $G$ ve $M$ ) and antiphosphatidylserine antibodies (IG $G$ ve $M$ ) were measured. Results. There was no statistical significance between preeclampsia and control group for antiphospholipid antibodies but these were two times higher in preeclamptic group compared to control group. (22.2\% in preeclampsia, $11.3 \%$ in control group $\mathrm{p}=0.193)$. Conclusions. In an unselected population we were not able to demonstrate an association between preeclampsia and antiphospholipid antibody syndrome but antiphospholipid antibody ratio elevated in women with preeclampsia. These findings show that, there is a need for large scale studies.
\end{abstract}

Keywords: Preeclampsia, antiphospholipid antibodies, pregnancy

\section{Özet}

Amaç. Bu çalışmanın amacı preeklampsi ve antifosfolipid antikor sendromu arasında ilişki olup olmadığının belirlenmesidir. Yöntem. Çalışmaya 20-40 hafta arasındaki toplam 116 gebe katılmıştır. Preeklampsi tanısı alan 63 hasta çalışma grubumuzu oluşturmuştur. Kontrol grubuna sağlıklı, normotensif ve sistemik hastalığı olmayan 53 gebe dahil edilmiştir. Çalışma ve kontrol grubunda bulunan gönüllülerden antifosfolipid antikoru olarak lupus antikoagülan, anti kardiolipin antikorları (IG $\mathrm{G}$ ve $\mathrm{M}$ ) ve antifosfatidilserin antikorları (IG $\mathrm{G}$ ve $\mathrm{M}$ ) çalışılmıştır. Bulgular. Preeklampsi ve konrol grubu arasında antifosfolipid antikor sendromu açısından istatistiksel olarak anlamlı farklılık saptanmamıştır ancak bu antikorlar kontrol grubu ile karşılaştırıldığında, preeklamptik grupta iki kat daha yüksek olarak saptanmıştır. (preeklampside \%22,2 kontrol grubunda \%11,3) $\mathrm{P}=0,193$. Sonuç. Bu çalışmada preeklampsi ve antifosfolipid antikor sendromu arasında ilişki gösterilememiştir ancak preeklamptik hastalarda antifosfolipid antikorlarının yüksek olarak saptanması daha geniş çaplı ve çalışmalara gereksinim olduğunu göstermektedir.

Anahtar sözcükler: Preeklampsi, gebelik, antifosfolipid antikor sendromu

Geliş tarihi/Received: 23 Haziran 2012; Kabul tarihi/Accepted: 25 Ocak 2013

\section{*Corresponding author:}

Dr. Gökhan Açmaz, Kadın Hastalıkları ve Doğum Kliniği, Kayseri Eğitim ve Araştırma Hastanesi, TR-38010 Kayseri. E-posta: gokhanacmaz@gmail.com 


\section{Introduction}

Preeclampsia is a systemic disorder characterizied by hypertension, edema and proteinuria in which a diffuse vascular damage with deposition of fibrin is well recognised patholojical feature. It is displayed that prevalance of preeclampsia is 5-7\% of all pregnancies. It can have a major impact on both perinatal and maternal morbidity. It is one of the most causes of the direct maternal deaths throughout the world $[1,2]$.

Pregnancy is a hypercoagulibility state. It is claimed that abnormality of natural coagulation inhibitor level, immunolocig parameters and genetic parameters create a great tendency towards preeclampsia. [3]

Immunolocig fragment of thrombophilia is associated with antiphospholipid antibodies (APA) that related to variety of medical problems including recurrent spontaneous abortion, foetal death, and arterial and venous thrombosis which is major cause of the acquired thrombophilia. A pregnant that carries characteristic clinical and biochemistrical features of preeclampsia with specified levels of APA is considered to have antiphospholipid syndrome (APAS) [4, 5].

APAS is an autoimmune condition in which venous or arterial thrombosis is a primary clinical feature. If this sendrome is associated with an outoimmun disease, called primary likewise sistemic lupus eritramatosus however not, called secondary disease and both of them have same clinical features for pregnacies [6].

Some studies have also detected elevated levels of APA in women with preeclampsia [78]. These antibodies are most likely to be present in patients with early-onset (before 34 weeks' gestation) severe preeclampsia [9]. However, others found no association between APA and preeclampsia [10,11]. This situation shows that relationship between APA and preeclampsia remains uncertain.

During pregnancy, thrombosis and placental infarction have been implicated in some complications, for instance recurrent foetal wastage, idiopathic foetal growth restriction (FGR), and preeclampsia. Some of outhors claim that this thrombotic predisposition is apparently linked to APA in women $[12,13]$.

It was important to test for those antibodies during complicated pregnancies, in particular during preeclampsia, to determine possible predictive or therapeutic effects. Despite contrasting results, some authors suggested thromboprophylaxis during APA-associated pregnancies [14].

This study is aimed to clarify relationship between preeclamptic pregnancies and APAS and evaluate the role of APA (anticardiolipin antibodies (ACA), antiphosphatidylserine antibodies and lupus anticoagulant (LA) in preeclamptic and eclamptic pregnancies.

\section{Materials and methods}

A total of 116 pregnant women between 20th and 40th weeks of gestation admitted to our department were investigated. 53 pregnant women with uncomplicated healty pregnancies constituted our control group and 63 women with undefined type of preeclampsia constituted our study group. This study was carried out within a year. Women who reported histories of preeclampsia were not eligible to be controls. Patients with multiple pregnancies, with cronic renal and vascular disease or previous thromboembolic complications were excluded and women who is taking anticoagulant therapy or having preeclampsia superimposed on chronic hypertesion were not included in the study. None of the patients or controls was in labor at the time of sampling. All patients delivered in the Obstetrics Department of Erciyes University Faculty of Medicine and were fallowed until discharged from hospital. This study was approved by the etics comitte for human research at Erciyes University Kayseri/Turkey. 
Diagnose of preeclampsia was done according to the criteria agreed by the National High Blood Pressure Education Program Working Group of National Institutes of Health (NIH) in 2000. Preeclampsia was defined as blood pressure (BP) of at least $140 / 90 \mathrm{mmHg}$ after 20 weeks gestation on at least two occasions 6 hours apart when the absence of gestational trophoblastic disease or multiple pregnancies was confirmed by ultrasonografic examination, with proteinuria more than $0.3 \mathrm{~g}$ per 24 hours and edema < $1+$ after bed rest. Blood was measured with a calibrated aneroid manometer in the spine position after five minutes rest. Absolute diastolic blood pressure of $\geq 110 \mathrm{mmHg}$ and proteinuria $(\geq 2+[100 \mathrm{mg} / \mathrm{dL}]$ on a chateterized specimen was diagnostic for severe preeclampsia at admission.

Patients who were diagnosed as preeclampsia and had grand-mal seizure were defined as eclampsia. Gestational age was estimated from the first day of last menstrual period and confirmed by ultrasonografic measurments. The APS is diagnosed by the presence of two major components, one clinical and the other a laboratory finding. At least one clinical occurrence of either vascular thrombosis, other than superficial venous thrombosis, or one of several pregnancy morbidities, such as preeclampsia. Persistent presence in the serum of at least one type of antiphospholipid antibody.

Participants were divided into four groups according to their gestational age. Control group allocated into two groups; the first group was constituted by uncomplicated healty pregnants with <34th (early onset) weeks of gestation and the second group was constituted by uncomplicated healty pregnants with $>34$ th (late) weeks of gestation. Third group was constituted by <34th (early onset preeclampsia) weeks of gestation whose pregnancy was complicated with preeclampsia or eclampsia and fourth group had similar clinic features likewise third whose pregnancy were at the $>34$ th weeks of gestation.

After all patients were informed about trial and got their constent, $20 \mathrm{~mL}$ of blood was taken from the antecubital vein into plastic tubes at admission. All samples were studied relevant laboratories by the same technician after 10 minutes from taking blood samples for avoid laboratory mistake. ACA IG G, M and APS IG G, M, (antiphosphatidylserine antibody) were measured by enzyme-linked immunoassay (ELISA) technique using the enzyme-linked immunoassay Euroimmun kit; a range between 0 and $12 \mathrm{iu} / \mathrm{ml}$ was considered as normal. The plasma LA was measured using Biomerux LA kit with photometric clot detection principle, considering normal a range of values between 0.6 $1.2 \% / \mathrm{mL}$.

All of continuous variables were subjected to normality testing using the KolmogorovSmirnov method and data were expressed as mean \pm S.D. and median (min-max). Continuous variables were analyzed with non-parametric methods. Differences between control and preeclamptic groups were evaluated with Mann Whitney $U$ test and chisquare was used for comparing catagoric values. $\mathrm{P}$ values by Fischer exact test were reported for $2 \times 2$ tables when the assumptions for the chi-square analysis were not met. Data were stored and analyzed with The Statistical Package for Social Scienses (SPSS), relase 13.0 (Chicago IL) for Windows. Statistical significance was defined as $\mathrm{p}<0.05$.

\section{Results}

Charasteristics of patients in study and control groups are listed on table 1. There was no statistical significance between control and study group for parity $(\mathrm{p}>0.05)$. Nineteen (35.8\%) patients of 53 healty pregnants were primigravid and $34(64.2 \%)$ of them were multigravid. Twenty-three $(36.5 \%)$ patients of 63 preeclamptic pregnants were primigravid and $40(63.5 \%)$ of them were multigravid.

We did not detect difference between control and study groups for APA, $<34$ weeks of gestation and $>34$ weeks gestation and totally evaluated preeclamptic and healthy groups.

As illustrated in table 2; there was no statistical significance between control and study group for every stage of gestation but antibodies were seen in preeclamptic group two times more than control group ( $\mathrm{p}=302$ and 490). 
Table 1. Characteristics of the early onset, late onset preeclamptic pregnants and gestational week matched control groups.

\begin{tabular}{lllll}
\hline \multicolumn{1}{c}{ Groups } & \multicolumn{1}{c}{$\begin{array}{c}\text { Age } \\
\bar{x} \pm S D\end{array}$} & $\begin{array}{c}\text { 1. min. apgar } \\
\text { score } \bar{x} \pm S D\end{array}$ & $\begin{array}{c}\text { 5. min. apgar } \\
\text { score } \bar{x} \pm S D\end{array}$ & $\begin{array}{c}\text { IU EX } \\
\bar{x} \pm S D\end{array}$ \\
\hline $\begin{array}{l}\text { Early onset preeclampsia } \\
\text { (<34 weeks of gestation) }(\mathrm{n}=28)\end{array}$ & $27.86 \pm 5.63$ & $4.14 \pm 2.22$ & $5.71 \pm 2.69$ & $0.29 \pm 0.46$ \\
\hline Healthy control (<34 weeks of gestation) $(\mathrm{n}=23)$ & $27.72 \pm 5.84$ & $7.40 \pm 1.47$ & $9.36 \pm 1.63$ & $0.24 \pm 0.6$ \\
\hline P value & 0.929 & $<0.001$ & $<0.001$ & 0.378 \\
\hline $\begin{array}{l}\text { Late onset preeclampsia } \\
\text { (> 34 weeks of gestation)(n=35) }\end{array}$ & $29.72 \pm 6.93$ & $6.09 \pm 2.44$ & $7.89 \pm 2.82$ & $0.63 \pm 1.9$ \\
\hline Healthy control > 34 weeks of gestation $(\mathrm{n}=28)$ & $28.04 \pm 5.52$ & $7.68 \pm 0.99$ & $9.68 \pm 0.98$ & $0.21 \pm 0.42$ \\
\hline & 0.309 & 0.002 & 0.002 & 0.423 \\
\hline
\end{tabular}

Table 2. Comparing APA results among early onset preeclamsia (<34th weeks of gestation), late onset preeclampsia and healty pregnancies.

\begin{tabular}{llll}
\hline \multirow{2}{*}{ Groups } & \multicolumn{2}{l}{ (ACA IG G,IG M or APS IG G, IG M or LA) } & \\
\cline { 2 - 3 } & Pozitive & Negative & Total \\
\cline { 2 - 3 } & $\mathbf{n}(\boldsymbol{\%})$ & $21(75.0)$ & 28 \\
\hline $\begin{array}{l}\text { Preeclampsia (Pregnancies <34th } \\
\text { weeks of gestation) }\end{array}$ & $7(25.0)$ & $22(88.0)$ & 25 \\
\hline $\begin{array}{l}\text { Control (Pregnancies <34th weeks of } \\
\text { gestation) }\end{array}$ & $3(12.0)$ & $28(80.0)$ & 35 \\
\hline $\begin{array}{l}\text { Preeclampsia(Pregnancies >34th } \\
\text { weeks of gestation) }\end{array}$ & $7(20.0)$ & $25(89.3)$ & 28 \\
\hline $\begin{array}{l}\text { Control (Pregnancies >34th weeks of } \\
\text { gestation) }\end{array}$ & $3(10.7)$ & & 2902 \\
\hline
\end{tabular}

Table 3. Total evaluation of APA for both groups.

\begin{tabular}{|c|c|c|c|c|}
\hline \multirow{3}{*}{ Groups } & \multicolumn{4}{|c|}{ (ACA IG G,IG M or APS IG G, IG M or LA) } \\
\hline & Pozitive & Negative & & \\
\hline & n (\%) & n $(\%)$ & Total & $\mathbf{P}$ \\
\hline Preeclampsia & $14(22.2)$ & $49(77.8)$ & $63(54.3)$ & \\
\hline Control & $6(11.3)$ & $47(88.7)$ & $53(45.7)$ & 0.193 \\
\hline Total & $20(17.2)$ & $96(82.8)$ & $116(100.0)$ & \\
\hline
\end{tabular}

\section{Discussion}

The presence of APA significantly increases the risk of developing pre-eclampsia [7, 8]. However, when women who developed pre-eclampsia were matched with women who didn't, there are some conflicting among outhors. Many of the outhors have described increased rates of APA, ranging between $10 \%$ and $20 \%$, among women with preeclampsia, [15-17] severe preeclampsia, [18-19] or eclampsia [20]. On the other hand some of investigators have found no increased rate of APA among women with preeclampsia [21, 22].

The APS is diagnosed by the presence of two major components, one clinical and the other a laboratory finding. Clinical finding include; occurrence of either vascular thrombosis, other than superficial venous thrombosis, or one of several pregnancy morbidities, such as preeclampsia. Laboratory finding include; persistent presence in the serum of at least one type of antiphospholipid antibody. Participants were divided into four groups according to their gestational age. Control group allocated into two groups; the first group was constituted by uncomplicated healty pregnants with <34th (early onset) weeks of gestation and the second group was constituted by uncomplicated healty pregnants with $>34$ th (late) weeks of gestation. Third group was constituted by <34th (early onset preeclampsia) weeks of gestation whose pregnancy was complicated with preeclampsia or eclampsia and fourth group had similar clinic features likewise third whose pregnancy were at the $>34$ th weeks of gestation. In our unselected population we 
were unable to demonstrate an association between APAS and preeclampsia. On the other hand we detected similar ratios as many outhors who found positive correlation preeclampsia and antiphospholipid antibodies. One of the possible discrepancy mechanisim is size of control and study groups. For instance Van Pampus et al. [19] studied 345 patients with a history of severe preeclampsia, compared with 67 women who remained healty and normotensive during pregnancy. This study suggested that elevated levels of APA were more common in women with a history of severe preeclampsia compared with controls (20.9\% versus $7.5 \%)$. They reported that there were APAS in $20.9 \%$ of patients with a history of preeclampsia therefore they recommended that patients with preeclampsia or with a history of preeclampsia should be tested for acquired thrombophilia because of the high prevalance of thrombophilia in such woman. Thus thrombophilias may be a cause or an outcome of pregnancy associated hypertensive disorders. Despite our study did not demonstrate statistically significant APA in preeclampsia, we demonstrated similar ratios with Van Pampus et al. [19] (22.2\% versus 11.3\%). Redman et al. [23] suggested that preeclampsia is an extreme form of a universal maternal response to pregnancy whereby a systemic inflammatory response characteristic of normal pregnancy becomes excessive, causing a degree of decompensation in some maternal systems. In contrast Dreyfus et al. [24] claimed that APA were not capable of activating the coagulation cascade that already had been activated by another mechanism during preeclampsia such as abnormalities of other thrombophilia markers. Therefore, they consider that these APAs were natural nonpathogenic, innocent autoantibodies. Their study group was constituted from 180 pregnant with first incidents of preeclampsia and no histories of thrombosis or systemic autoimmune diseases.

Although we did not classified patients on this type and we did not find any statistically significant increase in APAs, we detected that incidence of APAs were two times higer in preeclamptic group so this situation might be a result of excessive respond in women with pregnancy associated hypertensive disorders [24].

In conclusion; despite contrasting results, some authors suggested thromboprophylaxis during antiphospholipid antibody-associated pregnancies. APA is positive for one of five pregnants whose pregnancy is compticated with preeclampsia. This study didn't prove statistical significance between preeclampsia and antiphospholipid antibodies however situation might arise from small size of groups. These findings show that, there is a need for large scale studies. Another study will have to determine the treatment strategies and predictive effect of anticoagulants, antiplatelets or steroids in antiphospholipid positive preeclamptic pregnants.

\section{References}

1. Davies JA. Prentice JRM. Coagulation chances in pregnancy-induced hypertension and growth restriction in: Greer IA. Turpie AGG. Forbes CD. Editors. Haemostasis and Thrombosis in Obstetrics and Gynecology London Chapman \& Hall 1992; pp: 143-62.

2. Duley L. Maternal mortality associated with hypertensive disorders of pregnancy in Africa, Asia, Latin America and the Caribbean. Br J Obstet Gynaecol 1992; 99: 547-53.

3. Vormittag R, Pabinger I. Thrombophilia and pregnancy complications. Hamostaseologie 2006; 26: 59-62.

4. Levine JS, Branch DW, Rauch J. The antiphospholipid syndrome. N Engl J Med 2002; 346: 752-63.

5. Wilson WA, Gharavi AE, Koike T, Lockshin MD, Branch DW, Piette JC, Brey R, Derksen R, Harris EN, Hughes GR, Triplett DA, Khamashta MA. International consensus statement on preliminary classification criteria for definite antiphospholipid syndrome: report of an international workshop. Arthritis Rheum 1999; 42: 1309-11.

6. Bick RL, Baker WF Jr. The antiphospholipid and thrombosis syndromes. Med Clin North Am 1994; 78: 667. 
7. Pattison NS, Chamley LW, McKay EJ, Liggins GC, Butler WS. Antiphospholipid antibodies in pregnancy: prevalence and clinical associations. Br J Obstet Gynaecol 1993; 100: 909-13.

8. Yasuda M, Takakuwa K, Tokunaga A, Tanaka K. Prospective studies of the association between anticardiolipin antibody and outcome of pregnancy. Obstet Gynecol 1995; 86: 555-9.

9. Branch DW, Andres R, Digre KB, Rote NS, Scott JR. The association of antiphospholipid antibodies with severe preeclampsia. Obstet Gynecol 1989; 73: 541-5.

10. Out HJ, Bruinse HW, Christiaens GC, van Vliet M, de Groot PG, Nieuwenhuis HK, Derksen RH. A prospective, controlled multicenter study on the obstetric risks of pregnant women with antiphospholipid antibodies. Am J Obstet Gynecol 1992; 167: 26-32.

11. Matthiesen LS, Berg G, Ernerudh J, Skogh T. A prospective study on the occurrence of autoantibodies in low-risk pregnancies. Eur J Obstet Gynecol Reprod Biol 1999; 83: 21-6.

12. Ginsberg JS, Demers C, Brill-Edwards P, Johnston M, Bona R, Burrows RF, Weitz J, Denburg JA. Increased thrombin generation and activity in patients with systemic lupus erythematosus and anticardiolipin antibodies: Evidence for a prothrombotic state. Blood 1993; 81: 2958-63.

13. Santoro SA. Antiphospholipid antibodies and thrombotic predisposition: Underlying pathogenetic mechanisms. Blood 1994; 83: 2389-91.

14. Rai R, Regan L. Obstetric complications of antiphospholipid antibodies. Curr Opin Obstet Gynaecol 1997; 9: 387-90.

15. Milliez J, Lelong F, Bayani N, Jannet D, el Medjadji M, Latrous H, Hammami M, Paniel BJ. The prevalence of autoantibodies during third-trimester pregnancy complicated by hypertension or idiopathic fetal growth retardation. Am J Obstet Gynecol 1991; 165: 51-6.

16. Sletnes KE, Wisløff F, Moe N, Dale PO. Antiphospholipid antibodies in preeclamptic women: relation to growth retardation and neonatal outcome. Acta Obstet Gynecol Scand 1992; 71: 112-7.

17. Allen JY, Tapia-Santiago C, Kutteh WH. Antiphospholipid antibodies in patients with preeclampsia. Am J Reprod Immunol 1996; 36: 81-5.

18. Moodley J, Bhoola V, Duursma J, Pudifin D, Byrne S, Kenoyer DG. The association of antiphospholipid antibodies with severe early-onset pre-eclampsia. S Afr Med J 1995; 85: 105-7.

19. van Pampus MG, Dekker GA, Wolf H, Huijgens PC, Koopman MM, von Blomberg BM, Büller HR. High prevalence of hemostatic abnormalities in women with a history of severe preeclampsia. Am J Obstet Gynecol 1999; 180: 1146-50.

20. Rao AA, Ananthakrishna NC. Anticardiolipin antibodies in eclampsia. Int J Gynaecol Obstet 1992; 38: 37-40.

21. Scott RA. Anti-cardiolipin antibodies and pre-eclampsia. Br J Obstet Gynaecol 1987; 94: 604-5.

22. Martínez-Abundis E, González-Ortiz M, Cortés-Llamas V, Salazar-Páramo M. Anticardiolipin antibodies and the severity of preeclampsia-eclampsia. Gynecol Obstet Invest 1999; 48: 168-71.

23. Redman CW, Sacks GP, Sargent IL. Preeclampsia: an excessive maternal inflammatory response to pregnancy. Am. J Obstet Gynecol 1999; 180: 499-506.

24. Dreyfus M, Hedelin G, Kutnahorsky R, Lehmann M, Viville B, Langer B, Fleury A, M'Barek M, Treisser A, Wiesel ML, Pasquali JL. Antiphospholipid antibodies and preeclampsia: a case-control study. Obstet Gynecol 2001; 97: 29-34. 